\title{
MENINGKATKAN KEMANDIRIAN ANAK DENGAN MENGGUNAKANMODEL PEMBELAJARAN DI LUAR KELAS DI KB DHARMA MULYA TENGGARONG SEBERANG TAHUN PELAJARAN 2016/2017
}

\author{
TUTIK \\ PG PAUD, FKIP, Universitas Widya Gama Mahakam Samarinda \\ ( masgeng587@gmail.com ) \\ Harry Gunawan \\ PG PAUD, FKIP, Universitas Widya Gama Mahakam Samarinda \\ ( harygunawan77@yahoo.co.id)
}

\begin{abstract}
Concerning with the low level of autonomy on students of Class A in Dharma Mulya Playgroup Tenggarong, the researcher aims to investigate the effectiveness of outdoor education in improving students' independence, by conducting a classroom action research. The researcher applied two cycles, which in each cycle, consisting of planning, implementation, observation and reflection. Observation and documentation were employed in terms of data collection. Meanwhile, percentage analysis was carried out as data analysis. Moreover, as the research subjects, the researcher involved 30 students. At the first cycle, during three meetings, students' autonomy increased 59.4\%. Likewise, the percentage of students who successfully improved their autonomy inclined into $85.4 \%$. Having compared the percentage of students' autonomy in cycle 1 and cycle 2, students' had positivelyenhanced their autonomy for $25 \%$ in cycle 2 . Therefore, it can be concluded that the outdoor education has effectively increased students' autonomy in Class A of Dharma Mulya Playgroup Tenggarong. Subsequently, it is suggested for teachers to apply outdoor education as the alternative learning method which can increase students' self-sufficiency from $59.4 \%$ into $85.4 \%$.
\end{abstract}

Key words: outdoor education, students' autonomy

\section{PENDAHULUAN}

Pendidikan anak usia dini (PAUD) yang diselenggarakan sebelum jenjang pendidikan dasar, memiliki kelompok sasaran anak usia 0-6 tahun. Pada usia dini ini otak anak berkembang sangat pesat. Hasil penelitian yang dapat dipercaya menyatakan bahwa perkembangannya mencapai hingga lebih dari lima puluh persen maka usia dini adalah fase fundmental bagi perkembangan individu yang sering 
disebut sebagai masa emas atau golden age. Masa ini masa yang tepat untuk meletakkan dasar-dasar pengembangan kemampuan fisik, bahasa, sosial emosional, seni, moral, dan nilai-nilai agama (UU No 20 Tahun 2003, Pasal 1, Ayat 14).

Undang-undang Nomor 20 tahun 2003 Pasal 1 Ayat 1 tentang Sistem Pendidikan Nasional menyebutkan bahwa pendidikan adalah usaha sadardan terencana untuk mewujudkan suasana belajar dan peroses pembelajaran agar peserta didik dapat berperan aktif dan positif dalam mengembangkan potensi dirinya untuk memiliki kekuatan spritual agama, pengendalian diri, keperibadian, kecerdasan, akhlak mulia, serta keterampilan yang diperlukan dirinya, masyarakat, bangsa dan Negara.

Salah satu aspek yang dikembanagkan dalam pendidikan anak usia dini adalah sosial emosional, (1) Menunjukkan sikap mandiri dalam memilih kegiatan, (2) Mau berbagi, menolong, dan membantu teman, (3) Menunjukan antusiasme dalam melakukan permainan kompetitif secara positif, (4) Mengendalikan perasaan, (5) Menaati aturan yang berlaku dalam suatu permainan, (6) Menunjukkan rasa percaya diri, (7) Menjaga diri sendiri dari lingkungannya.dan (8) Menghargai orang lain. ( Peraturan Menteri Pendidikan No. 58 Tahun 2009).

Pada anak, istilah ke-mandirian umumnya dikaitkan dengan kemampu an untuk melakukan segala sesuatu-nya sendiri. Apakah itu memakai baju sendiri, menalikan sepatunya sendiri, makan sendiri, dan melakukan hal-hal yang sederhana sendiri tanpa harus tergantung pada bantuan orang lain.

Sikap mandiri anak harus dibina sejak usia dini, seandainya sikap mandiri anak ditanamkan setelah anak besar, sikap mandiri itu akan menjadi tidak utuh. Secara alamiah anak sudah mempunyai dorongan untuk mandiri atas dirinya sendiri.Mereka terkadang lebih senang untuk biasa mengurus dirinya sendiri dari pada dilayani. Sayangnya orang tua sering menghambat keinginannya dan dorongan untuk menjadi mandiri. Sikap mandiri yang diajar kan pada anak sejak dini akan membuatnya, dapat mengatur waktu kegiatannya sendiri dan membuat anak terbiasa menolong orang lain serta lebih bisa menghargai orang lain. Oleh karena itu sikap mandiri pada anak sangat diperlukan karena dengan kemandirian, anak bisa menjadi lebih bertanggung jawab dalam memenuhi kebutuhannya.

Kemandirian anak sangat perlu ditingkatkan, karena sangat menentukan 
kemampuan lainnya seperti rasa tanggung jawab, toleran terhadap teman sebaya. Kemandirian sangat berguna bagi anak anak untuk tahap pendidikan selanjutnya.

Berdasarkan pengamatan pada siswa KB Dharma Mulya Tahun Ajaran 2016/2017 menunjukan bahwa sebagian besar masih banyak anak yang belum dapat melakukan kegiatan dan bermain dengan mandiri, anak tidak mau beradaptasi dengan anak sebayanya. Sehingga pada kegiatan bermain bersama anak masih memiliki keegoisan yang tinggi dan masihbanyak anak yang ingin menguasai mainan sendiri, tidak mau membagi mainan dengan teman yang lainnya.Dapat kita ketahui bahwa kemandirian anak perlu dikembangkan, berdasarkan pemikiran diatas peneliti tertarik untuk melakukan penelitian di KB Dharma Mulya yang berjudul "Meningkatkan Kemandirian Anak dengan Menggunakan Model Pembelajarandi Luar Kelas di KB Dharma Mulya Tenggarong Seberang Tahun Ajaran 2016/2017”.

\section{METODE PENELITIAN}

\section{Desain Penelitian.}

Penelitian tindakan kelas adalah penelitian yang memaparkan terjadinya seba-akibat dri perlakuan, sekaligus memaparkan apa saja yang seluruh proses sejak awal pemberian perlakuan sampai dengan dampak dari perlakuan tersebut (Arikunto:2016:1). Dengan demikian peneltian tindakan kelas (PTK) adalah jenis penelitian yang memaparkan baik proses maupun hasil, yang melakukan PTK di kelasnya untuk meningkatkan kualitas pembelajaran.

\begin{tabular}{lrr}
\multicolumn{1}{c}{ Desain } & penelitian ini & adalah \\
deskripsi & kualitatif, & artinya \\
memaparkan & proses & untuk
\end{tabular}
meningtkatkan kemampuan motorik halus anak usia 4-5 tahun. Peneliti mencari penyebab tidak ada motivasi siswa dalam mengikuti kegiatan dengan kemauan sendiri, dan ketidak sanggupan siswa menyelesaikan tugas sedniri ketika bermain.

Penelitian Tindakan Kelas merupakan rangakaian tiga buah kata yang masing-masing dapat dijelaskan sebagai berikut :

1. Penelitian : menunjuk pada suatu kegiatan suatu objek dengan menggunakan cara dan metodologi tertentu untuk memperoleh data atau informasi.

2. Tindakan : menunjuk pada suatu gerak kegiatan yang dengan sengaja dilakukan dengan tujuan tertentu.

3. Kelas : sekelompok peserta didik yang dalam waktu yang sama, belajar hal yang sama dari pendidik yang sama pula. 


\section{Subjek Penelitian}

Subjek Penelitian Tindakan Kelas adalah anak didik pada Kelompok A KB Dharma Mulya Tenggarong Seberang yang berjumlah 30 siswa semester pertama tahun pelajaran 2016/2017. Subjek yang penulis teliti dalam kemandirian:

1. Dapat menyemai biji atau benih tanama

2. Dapat merawat tanaman

3. Dapat memasukkan tanah ke dalam pot atau polybag

4. Mampu mebedakan biji atau benih tanaman

\section{Prosedur Penelitian}

Prosedur penelitian ini eksperimen berulang atau eksperimen berkelanjutan, maksudnya apabila hasil dari pembelajaran belum mencapai indikator keberhasilan, maka peneliti melakukan metode pembelajaran yang lebih menarik, dan dilakukan berulang-ulang untuk mencapai indikator keberhasilan.

Penelitian ini merencanakan melakukan 3 siklus, penelitian tindakan ini dimulai dari perencanaan, pelaksanaan, pengamatan dan refleksi.Dan apabila dalam satu siklus belum mencapai indikator keberhasilan maka diadakan pengulangan dimulai dari pelaksanaan dan pengamatan saja, pengulangan dilakukan sebanyak tiga kali hanya pengamatan dan pelaksanaan saja. Pengulangan pertama melakukan metode yang lebih menarik minat anak, pengulangan kedua bertujuan untuk pembenahan apabila belum mencapai indicator keberhasilan, pengulangan ketiga bertujuan untuk memantapkan bahwa metode dan cara untuk mencapai indikator keberhasilan. Setelah melakukan pengulangan tiga kali peneliti melakukan refleksi terhadap anak, karena anak adalah yang mengalami proses tindakan dari awal sampai selesai.

\section{Teknik Pengumpulan Data}

\section{Observasi (Pengamatan)}

Observasi adalah teknik pengumpulan data dengan carapengamatan secara langsung dan ikut terlibat dalam pengamatan tersebut, yang dilaksanakan pada kelompok AKB Dharma Mulya Kecamatan Tenggarong Seberang. Adapuncara melakukannya penelitian ini melakukan dengan teknik observasi terfokus yaitu observasi yang dilakukan secara khusus yang ditujukan untuk mengamati aspek-aspek tertentu dari pembelajaran.

\section{Dokumentasi}

Dokumentasi dilakukan dengan cara mengambil gambar untuk memberi gambaran tentang situasi dan kondisi pada saat pembelajaran di KB Dharma MulyaTenggarong Seberang. Pengumpulan instrument-instrumen 
penelitian berupa lembar observasi siswa dan lembar observasi guru, profil sekolah, struktur organisasi sekolah dan data siswa selama penelitian ini berlangsung.

\section{Teknik Analisis Data}

Data yang akan di kumpulkan dalam penelitian tindakan kelas ini berupa data kuntitatif. Data kuantitatif akan diolah mengunakan uji deskripsi melalui prosentase dengan rumus :

$$
\mathrm{N}=\underline{\mathrm{Y}} \times 100 \%
$$

\section{Keterangan :}

$\mathrm{N}$ : Persentase ketuntasan belajar siswa

$X$ : Jumlah siswa yang tuntas belajar

Y : Jumlah siswa keseluruhan

\section{Indikator Keberhasilan}

Penelitian tindakan kelas ini baru dikatakan berhasil dengan baik apabila ada peningkatan pada siklus 1 dan 2 secara signifikan terhadap kemandirian anak melalui kegiatan bermain sebesar $85 \%$.

Berikut ini tabel interval kategori penilaian kemandirian anak dalam kegiatan menanam.

Kreteria penilaian yang dipakai untuk menuntaskan penelitian ini adalah anak yang mendapatkan skor 4 (baik) dan 5 (baik sekali)
Tabe. 1

Kategori penilaian hasil observasi

\begin{tabular}{|l|l|}
\hline $\begin{array}{l}\text { Presentasi } \\
\text { keberhasilan belajar }\end{array}$ & $\begin{array}{l}\text { Kriteria } \\
\text { penilaian }\end{array}$ \\
\hline $0 \%-20 \%$ & Kurang sekali \\
\hline $21 \%-40 \%$ & Kurang \\
\hline $41 \%-60 \%$ & Cukup \\
\hline $61 \%-80 \%$ & Baik \\
\hline $81 \%-100 \%$ & Baik sekali \\
\hline
\end{tabular}

\section{TEMUAN DAN PEMBAHASAN}

\section{Temuan}

\section{Kondisi Awal Penenlitian Sebelum} Tindakan

Hasil pengamatan awal yang diperoleh melalui lembar observasi mengenai kemandirian anak pada kelompok A di TK Kelompok Bermain Dharma Mulya tahun pembelajaran 2016-2017 semester 1 menunjukkan bahwa dari 30 anak hanya ada 5 anak $(16,7 \%)$ sudah menunjukkan kemandirian dalam kategori baik, dan sisanya 24 anak (83,3\%) belum memiliki kemandirian dengan baik, anak masih selau minta didampingi orang tua dan sangat tergantung dengan bantuan guru.Peneliti menentukan nilai ketuntasan yaitu nilai yang mendapat skor 4 dan 5 (baik dan baik sekali). Dari data lembar observasi pada pengamatan awal tidak ada satu anakyang mendapat nilai sangat baik, sebagaimana dalam tabel berikut ini : 
Tabel 2

Hasil Pengamatan Kemandirian Anak Melalui Kegiatan Bermain di luar Kelas Sebelum Tindakan

\begin{tabular}{|c|c|c|c|c|c|c|}
\hline \multirow[t]{3}{*}{ No. } & \multirow{3}{*}{$\begin{array}{l}\text { Aspek yang } \\
\text { dinilai }\end{array}$} & \multicolumn{5}{|c|}{ Skor yang dicapai } \\
\hline & & 1 & 2 & 3 & 4 & 5 \\
\hline & & \multicolumn{5}{|c|}{$\%$} \\
\hline 1. & $\begin{array}{l}\text { dapat } \\
\text { menyemai } \\
\text { biji atau } \\
\text { benih } \\
\text { tanaman }\end{array}$ & 50 & 26,7 & 6,7 & $\begin{array}{l}16, \\
7\end{array}$ & 0 \\
\hline 2. & $\begin{array}{l}\text { dapat } \\
\text { merawat } \\
\text { tanaman }\end{array}$ & 40 & 30 & $\begin{array}{l}13, \\
3\end{array}$ & $\begin{array}{l}16, \\
7\end{array}$ & 0 \\
\hline 3. & $\begin{array}{l}\text { dapat } \\
\text { memasukan } \\
\text { tanah ke } \\
\text { dalam pot }\end{array}$ & $\begin{array}{l}33 \\
, 3\end{array}$ & 33,3 & $\begin{array}{l}16, \\
7\end{array}$ & $\begin{array}{l}16, \\
7\end{array}$ & 0 \\
\hline 4. & $\begin{array}{l}\text { Merapikan } \\
\text { alat dan } \\
\text { perlengkapa } \\
\text { n bermain }\end{array}$ & $\begin{array}{l}26 \\
, 7\end{array}$ & 43,3 & $\begin{array}{l}13, \\
3\end{array}$ & $\begin{array}{l}16, \\
7\end{array}$ & 0 \\
\hline \multicolumn{2}{|c|}{ Nilai rata-rata } & $\begin{array}{l}37 \\
, 5\end{array}$ & 32,5 & $\begin{array}{l}12, \\
5\end{array}$ & $\begin{array}{l}16, \\
7\end{array}$ & 0 \\
\hline
\end{tabular}

Berdasarkan pengamatan awal kemandirian anak dengan kategori kurang sekali $37,5 \%$, kurang 32,5\%, cukup $12,5 \%$, dan baik $16,7 \%$, maka nilai ketuntasan kemandirian anak sebelum melakukan tindakan adalah $16,7 \%$. Nilai rata-rata tersebut jauh dari ketuntasan yang ditentukan dalam penelitian ini, yaitu indikator keberhasilan $75 \%$.

\section{Deskripsi Hasil Penelitian}

Penelitian tindakan kelasdilakukan pada semester 2, minggu pertama dan minggu kedua bulan Februari. Dengan subjek peneliti kelompok A dengan jumlah siswa 30 anak di Kelompok Bermain Dharma Mulya Tenggarong Seberang.
Data yang akan di kumpulkan dalam penelitian tindakan kelas ini berupa data kuntitatif. Data kuantitatif akan diolah mengunakan uji deskripsi melalui prosentase dengan rumus :

$$
\mathrm{N}=\underline{\mathrm{X}} \times 100 \%
$$

Keterangan :

$\mathrm{N}$ : Persentase ketuntasan belajar siswa $X$ :Jumlah siswa yang tuntas belajar

$\mathrm{Y}$ : Jumlah siswa keseluruhan

\section{Hasil pengamatan siklus}

Peningkatan kemandirian anak pada tiap pertemuan mengalami peningkatan, dan dapat dilihat pada tabel berikut ini :

Tabel 3

Data Rekapitulasi Peningkatan Kemandirian Anak Melalui Kegiatan Bernain di luar dengan Skor 4 dan 5Siklus 1

\begin{tabular}{|c|l|l|l|l|l|}
\hline No. & $\begin{array}{l}\text { Aspek } \\
\text { yang } \\
\text { dinilai }\end{array}$ & P 1 & P 2 & P 3 & $\begin{array}{l}\text { Nilai } \\
\text { rata- } \\
\text { rata }\end{array}$ \\
\hline 1. & $\begin{array}{l}\text { dapat } \\
\text { menyemai } \\
\text { biji atau } \\
\text { benih } \\
\text { tanaman }\end{array}$ & $50 \%$ & $60 \%$ & $\begin{array}{l}66,7 \\
\%\end{array}$ & $59 \%$ \\
\hline 2. & $\begin{array}{l}\text { dapat } \\
\text { merawat } \\
\text { tanaman }\end{array}$ & $50 \%$ & $\begin{array}{l}56,7 \\
\%\end{array}$ & $70 \%$ & $59 \%$ \\
\hline 3. & $\begin{array}{l}\text { dapat } \\
\text { memasuk } \\
\text { an tanah } \\
\text { ke dalam } \\
\text { pot/poly } \\
\text { bag }\end{array}$ & $55,8 \%$ & $\begin{array}{l}53,3 \\
\%\end{array}$ & $\begin{array}{l}66,6 \\
\%\end{array}$ & $58,5 \%$ \\
\hline 4. & $\begin{array}{l}\text { merapikan } \\
\text { alat dan } \\
\text { perlengka } \\
\text { pan } \\
\text { bermain }\end{array}$ & $56,7 \%$ & $\begin{array}{l}56,7 \\
\%\end{array}$ & $70 \%$ & $61 \%$ \\
\hline Nilai ketuntasan siklus 1 & & & \\
\hline Kategori & & & \\
\hline
\end{tabular}

Berdasarkan tabel 3, kemandirian anak antar pertemuan semakin meningkat dan nilai ketuntasan siklus 1 mencapai $59,4 \%$ belum mencapai nilai 
indikator keberhasilan, maka penelitian berlanjut pada siklus 2 .

\section{Hasil Pengamatan Siklus 2}

Peningkatan kemandirian anak dapat dilihat pada tabel rekapitulasi kemandirian anak antar siklus, sebagai berikut :

Tabel. 4

Data Rekapitulasi Peningkatan Kemandirian Anak Melalui Kegiatan Bernain di luar Kelas dengan skor 4 dan 5 antar siklus

\begin{tabular}{|c|c|c|c|}
\hline No. & Aspek yang dinilai & Siklus 1 & Siklus 2 \\
\hline 1. & $\begin{array}{l}\text { dapat menyemai biji } \\
\text { atau benih tanaman }\end{array}$ & $59 \%$ & $84,1 \%$ \\
\hline 2. & $\begin{array}{c}\text { dapat merawat } \\
\text { tanaman }\end{array}$ & $59 \%$ & $85,3 \%$ \\
\hline 3. & $\begin{array}{l}\text { dapat memasukan } \\
\text { tanah ke dalam } \\
\text { pot/poly bag }\end{array}$ & $59 \%$ & $87,7 \%$ \\
\hline 4. & $\begin{array}{l}\text { merapikan alat dan } \\
\text { perlengkapan } \\
\text { bermain }\end{array}$ & $61 \%$ & $84,4 \%$ \\
\hline & Nilai ketuntasan & $59,4 \%$ & $85,4 \%$ \\
\hline
\end{tabular}

Kegiatan pembelajaran di luar kelas meningkatkan kemandirian anak, kenaikan peningkatan kemandirian anak seperti pada grafik di bawah ini :

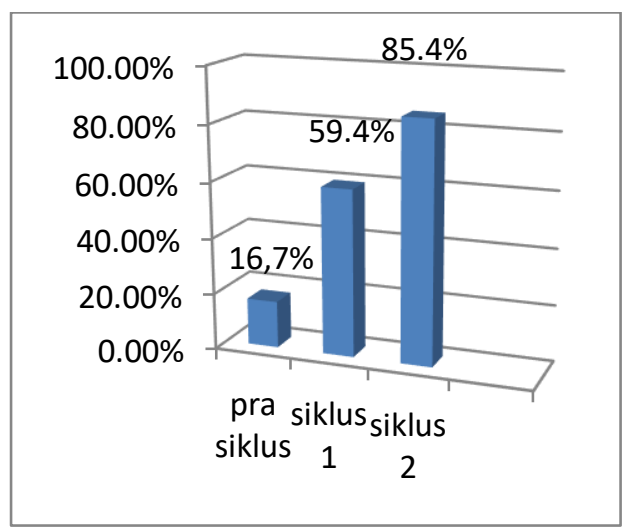

Grafik 1. Peningkatan Kemandirian antar Siklus

\section{Pembahasan Hasil Penelitian}

Hasil penelitian tindakan kelas dalam rangka meningkatkan kemandirian pada kelompok A di Kelompok Bermain Dharma Mulya Tenggarong Seberang sebagai berikut:

1. Secara umum semakin meningkatnya kemandirian anak dari siklus ke siklus menunjukkan kriteria peningkatan kualitas dapat menyemai biji atau benih tanaman, dapat merawat tanaman, dapat memasukkan tanah ke dalam pot dan merapikan alat dan perlengkapan mencapai nilai ratarata yang terus meningkat pada tiap pertemuan antar siklus.

2. Meskipun anak dalam usia muda tetapi juga membutuhkan kemandirian sebagai kebutuhan fisik mereka, seperti dikatakan menurut Winnieott bahwa belajar untuk tumbuh dan berkembang secara cepat dan tidak terduga. Anak akan memperoleh kebiasaan dengan apa mereka bermain, apa mereka senangi untuk dimakan dan kapan mereka untuk tidur. Semua hal merupakan kebutuhan fisik mereka anak dapat mengatakan apa yang mereka inginkan dan mengajak tanggung jawab seperti membereskan mainan yang berserakan / berhamburan.Sudah 
merupakan awal bahwa anak telah mandiri.mandiri. Penanaman sifat kemandirian ini harus sejak awal pra sekolah (Familia. 2006).

3. Secara keseluruhan aspek penilaian kemandirian anak mengalami peningkatan yaitu pada siklus 1 kemandirian anak mencapai $59,4 \%$ kemudian meningkat pada siklus 2 mencapai $85,4 \%$.

\section{PENUTUP}

\section{Kesimpulan}

Berdasarkan hasil penelitian yang telah dilakukan, maka dapat ditarik kesimpulan bahwa dengan model pembelajaran di luar kelas dapat meningkatkan kemandirian pada kelompok A di Kelompok Bermain Dharma Mulya Tenggarong Seberang tahun pembelajaran 2016-2017 dengan aspek penilaian sebagai berikut :

1. Dapat menyemai biji atu benih tanaman

2. Dapat merawat tanaman

3. Dapat memasukan tanah ke dalam pot

4. Merapikan alat dan perlengkapan bermain

Hal tersebut dapat dilihat dari hasil penelitian yang telah dilakukan melalui beberapa tindakan siklus 1 dan siklus 2 dengan 3 kali pertemuan berdasarkan seluruh pembahasan serta analisa yang didapat berdasarkan pada tabel rekapitulasi pada aspek :

1. Kemandirian anak dalam aspek dapat menyemai biji atau benih tanaman pada siklus 1kategori baik sekali mencapai 59\%, dan meningkat pada siklus 2 mencapai $84,1 \%$

2. Kemandirian anak dalam aspek dapat merawat tanaman ketegori baik sekali mencapai 59\% meningkat pada siklus 2mencapai $85,3 \%$

3. Kemandirian anak dalam aspek dapat memasukkan tanah ke dalam pot kategori baik sekali mencapai $59 \%$ dan meningkat pada siklus 2 mencapai $87,7 \%$.

4. Kemandirian anak dalam aspek dapat merapikan alat dan perlengkapan bermain dengan kategori baik sekali pada siklus 1 mencapai $61 \%$, kemudian meningkat pada siklus 2 mencapai $84,4 \%$

Berdasarkan uraian uraian di atas, maka peneliti menarik kesimpulan bahwa metode pembelajaran di luar kelas dengan kegiatan menanam bunga pacar air, kangkung dan kacang hijau dapat meningkatkan kemandirian, hal ini dapat dilihat pada partisipasi anak, dan kemauan anak ketika menanam, 
memasukkan tanah dan pupuk kandang ke dala pot.

\section{Saran}

1. Kepala Kelompok Bermain Dharma Mulya diharapkan agar selalu memberikan kesempatan bagi para guru untuk melakukan berbagai perbaikan pembelajaran termasuk melakukan penelitian tindakan kelas.

2. Para guru agar termotivasi untuk selalu melakukan berbagai aktivitas dalam meningkatkan profesionalitasnya sebagai upaya memperbaiki proses pembelajaran untuk meningkatkan hasil belajar.

3. Anak-anak agar selalu aktif selama pembelajaran berlangsung, mengikuti aturan yang diterapkan guru agar menjadi anak yang berkarakter, mengembangkan semua potensi yang dimilikinya supaya menjadi anak Indonesia yang diharapkan oleh bangsa dan negara

\section{DAFTAR PUSTAKA}

Abraham Maslow.1971. Panduan Pendidikan Anak Usia Dini. Jakarta : Gung Persada Pres.

Anonim. 2007. Penelitian Tindakan Kelas. Departemen Pendidikan Nasional Direktur Jenderal Penelitian Mutu Pendidikan dan Tenaga Kependidikan Jakarta.
Aqib, Zaenal. 2006. Penelitian Tindakan Kelas. Bandung; Yrama Widya.

Arikunto. Suharsimi,2016.Penelitian Tindakan Kelas.Jakarta: Bumi Aksara

Asrori. 2008. Panduan Pendidikan Anak Usia Dini. Jakarta.:Gung Persada Press.

Brewer. 2007. Pendidikan Anak Usia Dini. Jakarta : Gung Persada Press.

Desmitam, Drs. M. Si. 2009. Psikologi Perkembangan Peserta Didik. Bandung: Remaja Rosdakarya

Diane Trister Dogde. 2008. Panduan Pendidikan Anak Usia Dini. Jakarta : Gung Persada Press.

Depdiknas.2003. Kegiatan Belajar Mengajar Yang Efektif.Pusat Kurikulum Departemen Pendidikan Nasional. Jakarta.

Depdiknas. 2005. Kurikulum 2004 Standar Kompetensi TK/RA. Direktorat Jendral Pendidikan Dasar dan Menengah. Jakarta.

Depdiknas.2005. Pedoman Pembelajaran di Taman Kanak-kanak.Direktorat Jenderal Pendidikan Dasar dan Menengah. Jakarta.

Depdiknas.2005. Pedoman Penilaian di Taman Kanakkanak.Dikretorat Jenderal Pendidikan Dasar dan Menengah. Jakarta.

Hainstok, Elizabeth G. 2002. Mentessori Untuk Prasekolah. Jakarta : Pustaka Delapratasa. 
Hildayani, Rini.2009. Psikologi Perkembangan Anak. Jakarta : Universitas Terbuka

Jamilah Sabri Sanana, Dr, M. PdI. 2008. Panduan Pendidikan Anak Usia Dini. Jakarta :Gung Persada Press.

Hamalik, Oemar. 2001. Kurikulum dan Pembelajaran. Jakarta : BumiAksara.
Martini, Yamin. Dr, M.Pd. 2008.Panduan Pendidikan Anak Usia Dini.

Jakarta :Gung PersadaPress

Majid, Abdul. 2005. Perencanaan Pembelajaran. Bandung : Remaja Rosdakarya. 